\author{
Jūratè Matulionienè \\ Boston Lithuanian School Rūta, United Kingdom \\ Daiva Pundziuvienè \\ Vytautas Magnus University, Lithuania
}

\title{
CHALLENGES AND OPPORTUNITIES FOR UK IMMIGRANTS. LEARNING ENGLISH: A CASE STUDY OF ESOL CLASSES
}

\begin{abstract}
Summary. In the UK, the need for adult immigrants to learn English includes considerations for the recently arrived and those who have been living in the UK for a long time but still do not speak English; those in a wide variety of work situations; and those experiencing cultural shock. Such learners frequently have low self-esteem and often develop psychological barriers to speaking a foreign language. While most learning of English takes place in informal contexts, formal institutions in the UK and immigrants' native countries can also offer useful language training. In order to develop insight into adult learners' needs, this study used a survey to explore the participants' perceptions and experiences concerning learning English within an ESOL program, followed by semistructured interviews designed to provide deeper insight into the main obstacles to learning English. In addition, the study investigates an opportunity for UK immigrants to improve their competence in English, and for their children to study their parents' mother tongue, via an online learning program at a prominent Lithuanian university. The study revealed that the most important factors influencing learners' development of competence in English are their psychological well-being and belief in the progress of their English studies. The findings indicate a need for language teachers to develop innovative language learning strategies and address individual learning styles, as well as social, inter-cultural, cognitive, problem-solving and time management skills. Using a blended strategy of language learning could create more possibilities to develop competence in English in a way that is better adapted to learners' educational, linguistic and cultural backgrounds.
\end{abstract}

Keywords: English for speakers of other languages (ESOL), UK immigrants learning English, self-esteem and foreign language learning, acculturation, ESOL in the UK, inclusive teaching strategies, online learning.

\section{Introduction}

While many attempts have been made to explore the linguistic, cultural, psychological and many other difficulties that face UK immigrants while trying to adapt to their new country and culture, studies on how to provide effective English teaching programs and what teaching methods to apply are still of major 
importance. The common factors influencing the success or failure in improving newcomers' competence in English are numerous. It is important to have in mind that immigrants are often vulnerable and disadvantaged learners of English due to low self-esteem; lack of social skills; low self-confidence; little time and energy to study; insufficient literacy in their native language; ignorance of language learning strategies and individual learning styles; and finally, lack of motivation to learn a new language, as from the very beginning, they do not expect a successful and satisfactory learning process.

A teacher of ESOL working for an ESOL program notes that, although most UK immigrants realize that the major challenge to successful social integration is their lack of adequate English language skills, in reality it is very difficult to keep them motivated throughout the duration of their courses. Many adult ESOL learners, who usually come with very specific purposes and needs for learning, attend language courses of their own free choice, usually at considerable personal and financial sacrifice. If the courses fail to satisfy their needs, they will lose their motivation and simply stop coming to language classes. Relevance is perhaps the most important motivating factor for ESOL students. If students are exposed to life skills such as applying for a job, surviving in a foreign country, coping with culture shock, and so on, their motivation to study may be increased. A number of reputable scholars who focus on language teaching strategies in lifelong learning emphasize the importance of a motivating learning environment, where all activities are exciting and provide opportunities for real interaction with people, culture, language and the social environment (Biggs, 2011; Prince, 2004; Youngs, Ohsako, \& Medel-Añonuevo, 2001). Laurel (2010) suggests that language teaching activities should be exciting enough for students to not want to miss their class because they will be missing an 'action'. Moreover, Gravells (2012) states that establishing ground rules is important to create a safe working and learning environment, reinforce appropriate behavior and show respect for everyone in a multicultural and multilingual group of ESOL students.

Such students, coming from a wide variety of cultural and educational backgrounds, learning styles and abilities, require not only a special learning 
environment, but also specific teaching strategies. As Ambrose, Bridges, DiPietro, and Lovett (2010) emphasize, inclusive teaching strategies can help alleviate tension, as well as learners' dissatisfaction and low self-confidence, keeping in mind that:

Even though some of us might wish to conceptualize our classrooms as culturally neutral or might choose to ignore the cultural dimensions, students cannot check their socio-cultural identities at the door, nor can they instantly transcend their current level of development (pp. 169170).

Tisdell (1995) identified the following three important levels of inclusive teaching:

1. The diverse identity of language learners is the most important criterion that should be reflected in the curriculum, activities and methodology used by a language teacher.

2. Learning should be closely connected with the environment in which the participants work and live;

3. Learning content should reflect the changing the needs of an increasingly diverse society (p. 4).

In this respect, ESOL immigrant students' success in learning a foreign language is closely connected with their national identity, language, culture and personal experiences, as well as their teachers' efforts to appreciate this diversity and uniqueness. Thus, a teacher of ESOL for immigrant students should be aware of students' multiple perspectives as a result of their ethnicity, class, age, educational background, and emotional state, which might be influenced by culture shock, homesickness and many other factors.

As a means to meet immigrant learners' unique needs, the researchers believe that consideration may be given to various teaching tools. For instance, distance learning and online resources may be used to create a connection 
between immigrant language learners and their host and native countries. Virtual learning, when support, moderation and instructions are given in a learner's native language, may make the teaching process more learnercentered and relevant to individual learners' educational, social and cultural backgrounds.

\section{Research questions}

In order to better understand the needs of diverse immigrant learners of English living in the UK, as well as to identify tools and resources that may be of assistance in meeting these needs, the researchers addressed the following questions in this study:

1. What are the most important factors influencing the success of the UK immigrant learners of English in an ESOL program?

2. What teaching methodology may be effective in helping such learners to successfully integrate socially, linguistically and culturally into a new country?

3. Do learners believe that a blended strategy of language learning that includes ICT and distance learning increase their success in learning a foreign language?

The answers to these questions may enable the researchers to:

- identify the participants' most important studying goals before their participation in an ESOL course;

- evaluate the learners' positive and negative experiences in an ESOL course;

- $\quad$ analyze the learners' self-assessment of the skills improved in an ESOL course;

- investigate the students' attitudes toward the usefulness of different language teaching approaches, including a possible implementation of ICT, in the English language learning and teaching process; 
- explore the main psychological obstacles to learning English and how these factors have affected their learning of English;

- propose the employment of inclusive teaching strategies and the use of ICT as a bridge to enhance learning for ESOL students, as well as allowing their children or family members to study their mother tongue by attending language and culture courses presented online by their native countries in a distance learning or blended mode.

\section{Methodology}

A quantitative research methodology was applied, using a questionnaire to explore the needs, experiences and attitudes of the participants. The first section of the research instrument was composed of 7 close-ended questions and was designed to gather data about the participants' most important studying goals prior to participation in an ESOL course, their self-assessment of the skills they improved in an ESOL course, their attitudes toward the usefulness of various language teaching approaches, and a possible implementation of ICT in the English language learning and teaching process. The second section of the questionnaire focused on the participants' expectations and opportunities related to the learning of English. In addition to the closed-ended questions, several open-ended questions were included in both parts of the questionnaire. The data obtained were analyzed using frequencies and descriptive analysis.

Following the application of the questionnaire, interviews were conducted with the study participants in order to obtain deeper insight into the main obstacles and opportunities for learning English. The semi-structured interview format was chosen in order to encourage the students reflect on their learning experience and to assess the factors that positively or negatively affected their learning of English. The data were collected by the teacher of a commercial ESOL course in which the participants were enrolled. The interviews were conducted after the completion of an elementary level ESOL course. The interviewer had a paper-based interview guide with 6 open-ended questions 
prepared ahead of time. Due to the possibility of divergence of discussions from the interview guide, the interviews were recorded and transcribed for further analysis.

\section{Sample}

The research sample was selected on the basis of three criteria. Firstly, all of the participants were at the elementary level (level A1 according to the Common European Framework of Reference for Languages) of English language competence. Secondly, the respondents shared similar cultural and social backgrounds, as well as socio-economic status. Thirdly, their experiences as newcomers to the United Kingdom were relatively fresh, as the time spent in a new country as immigrants was not more than three months. The purpose of the study was explained to the participants prior to the application.

The participants were 14 Lithuanian and 2 Latvian learners of English enrolled in an ESOL course and is written from the perspective of a teacher who works with and teaches this group of adults. The respondents' education level is represented in Figure 1, while Figure 2 shows the representation of languages spoken at home in the UK by the respondents.

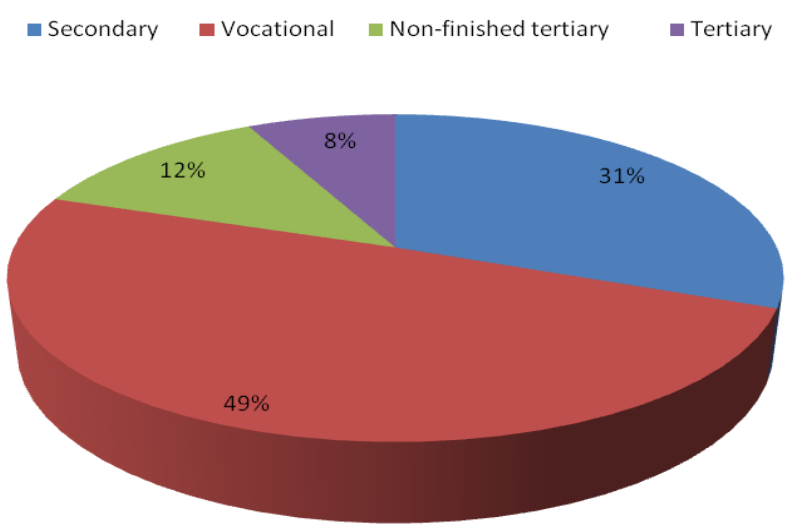

Fig. 1. Education level of the respondents 


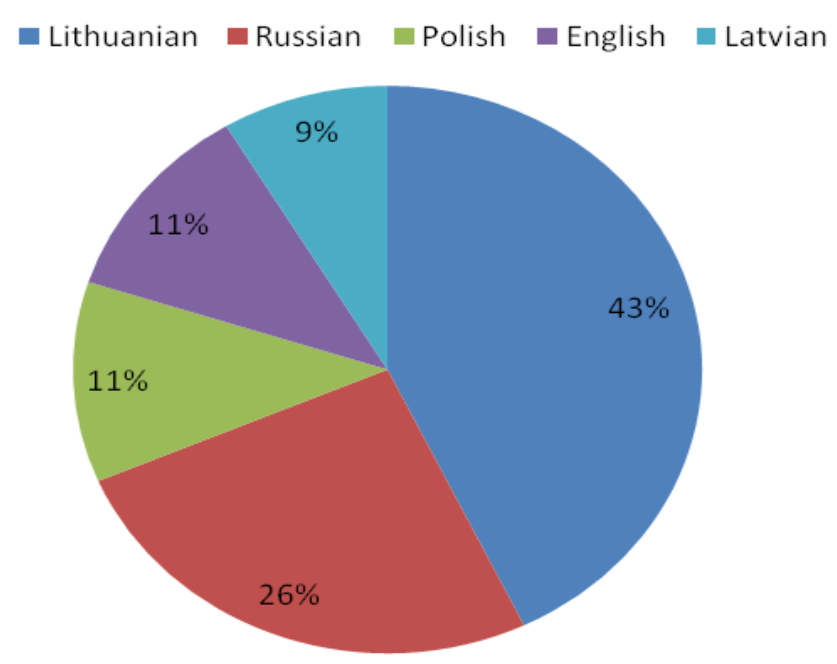

Fig. 2. Languages spoken at home in the UK

The students had varying levels of education, with the majority (49 percent) at a vocational level. Some of the respondents came from bilingual families where they reported that several languages were spoken at home in the UK. English was the first foreign language of all the respondents, and their average age, which ranged from 29 to 62 , was 38.4 years.

\section{Results}

Among the multiple challenges that UK immigrants face at both the personal and societal level is their understanding that job and career opportunities are limited for those who cannot speak English. The present study shows that most adult learners of English can offer a very different set of skills, knowledge and expectations to the classroom as individuals. As Figure 3 illustrates, most of the 
participants believe that English is a key step in adapting to the British way of life and is necessary for their survival in an English-speaking country.

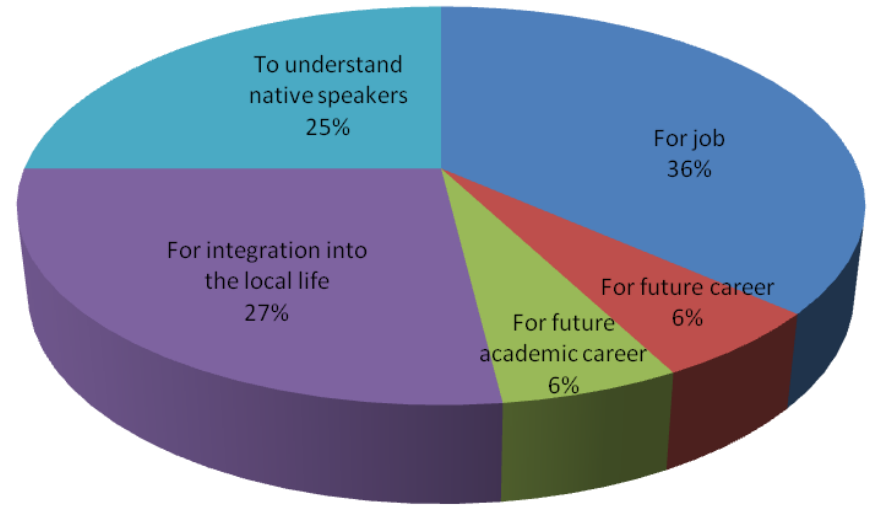

Fig. 3. Most important studying goals before participation in an ESOL course

According to the questionnaire results, 36 percent of the respondents expressed the need for English skills in order to find work; 27 percent felt a need to learn English for integration into local life; and 25 percent wanted to learn English to understand native speakers (25 percent). Only a few of the participants (6 percent) reported an academic career as a goal for learning, and another 6 percent saw learning English as a means to find a rewarding career in the new country. Keeping in mind that their competence in English was very basic, their expectations appeared to be realistic in this respect. In addition, as with Biggs (2011), Prince (2004), and Youngs, Ohsako, and Medel-Añonuevo (2001), the respondents mentioned the following as reasons for their need to learn English:

- the ability to communicate in public places;

- the need to feel more comfortable in public places and to understand the local language;

- $\quad$ and the necessity to get acquainted with local culture, traditions, social norms and customs. 
Furthermore, the majority of the respondents reported that their self-esteem was low in the new environment and believed that a higher competence in English could help to improve their self-confidence and well-being, as with Ambrose, Bridges, DiPietro, and Lovett (2010).

In addition to analyzing the most important studying goals before participation in an ESOL course, the researchers asked the participants to assess the skills they had already improved in the course. According to Blanche (1989), self-assessment is an important factor during the process of learning, as it fosters learner autonomy and students' awareness of their individual learning needs. The findings of the study indicate that the majority of the respondents consider that they have raised their competence in English grammar, reading, translating and listening skills and have enlarged their English vocabulary (see (see Figure 4).

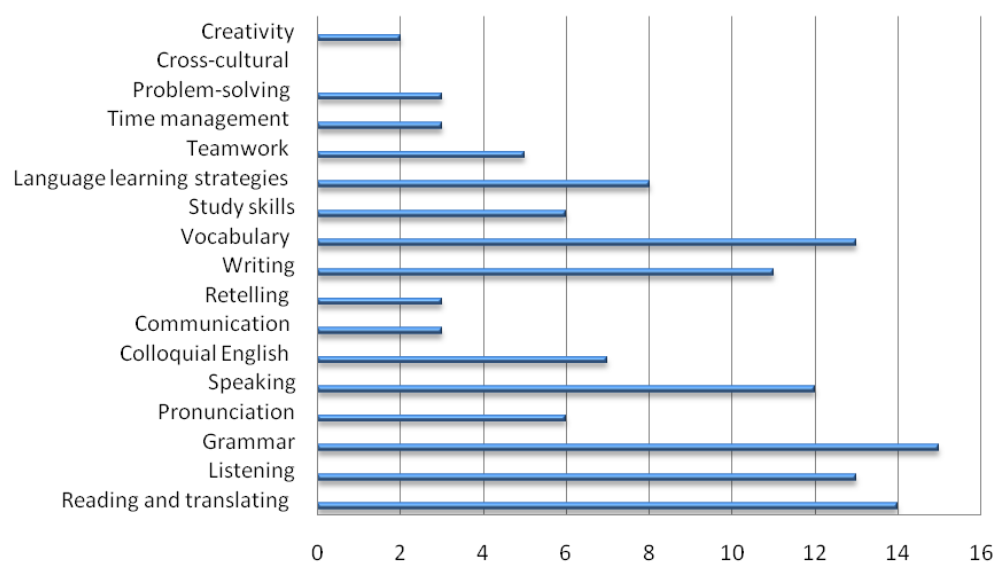

Fig. 4. Students' self-assessment of the skills improved in an ESOL course

The participants were also positive about their progress in speaking and writing in English. On the other hand, skills as creativity, problem-solving, time management and communication were marked only by a few respondents, which 
suggests that their focus on the acquisition of knowledge and skills oriented towards personal development is rather minimal. Such assessment of the students could be influenced by their attitude towards the above mentioned skills as unimportant and unrelated to language learning or by the teacher's lack of attention to the development of these skills during the course.

Finally, in spite of the importance of building cultural knowledge (Tisdell, 1995), the development of cross-cultural skills was not marked by any of the respondents. Whether these skills were not addressed by the teacher, or whether the participants were not focused on culture during the course, is not clear. In this sense, it is important to keep in mind that immigrant adult ESOL learners who are undergoing cultural and social adjustment, adaptation and acculturation, will be able to deal with cultural challenges more effectively if they are taught the necessary skills.

As the language learning experiences of adult learners is usually very different than that of children, it is very important to assess their previous knowledge and learning styles, as well as to ask them to evaluate the effectiveness of various approaches to learning and teaching ESOL. The respondents of the survey were asked to express their attitude toward the usefulness of different language teaching approaches, as illustrated in Figure 5.

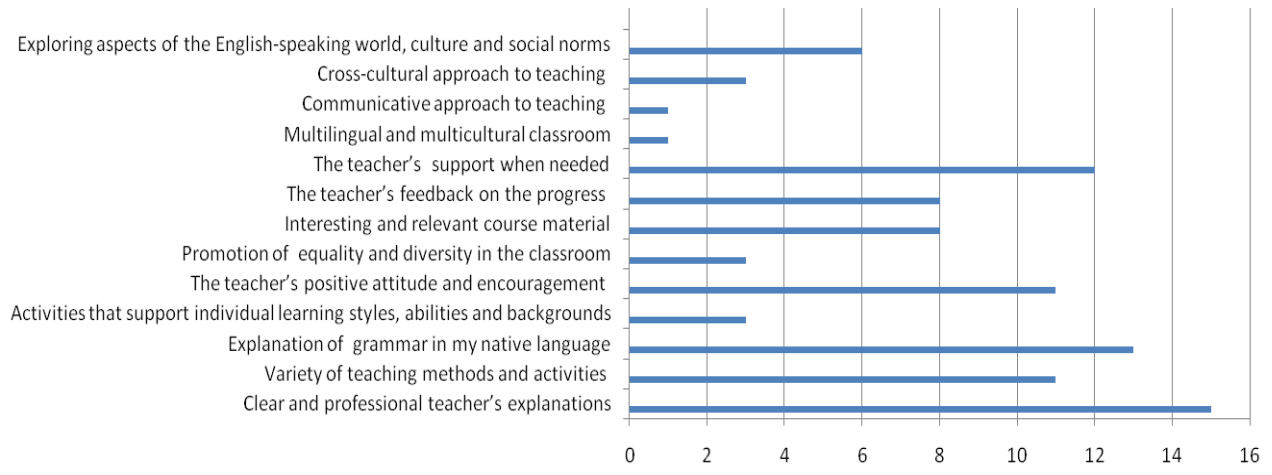

Fig. 5. Learners' attitudes toward the usefulness of different language teaching approaches 
As Figure 5 demonstrates, the participants strongly favored clear and professional explanations by the teacher, preferably in one's native language. Adult students are often vulnerable and need encouragement, because the learner's role is new and may be stressful. Accordingly, a large number of the participants mentioned the teacher's support, positive attitude and encouragement as very important factors influencing successful learning. Half of the respondents emphasize the importance of the teacher's feedback to their progress, as well as the need for interesting and relevant course material. Furthermore, less than one half of the participants reported that exploring different aspects of the English-speaking world, culture and social norms is useful for improving their English language competence. A possible explanation for this answer could be the students' ignorance of innovative language learning strategies focused on understanding and creating language that is appropriate to the social, cultural and communicative context. Such methodologies should be integrated into ESOL classes where students primarily need the language in order to function in a new unfamiliar environment.

Overall, the survey results revealed that the participants' approach to learning a new language was very traditional, as very few of them mentioned a cross-cultural or communicative approach to teaching as useful for language learning.

\section{The use of ICT to enhance learning for ESOL students}

The rapid advancement of information and communication technologies has boosted the use of an increasing variety of digital language teaching forms; e.g., online learning, e-learning, distance learning, blended learning, and so on. Information and Communication Technologies (ICT)-integrated language teaching creates learning possibilities for all members of society without constraints to time and place. The transfer of the teaching and learning process to a virtual learning environment could be especially beneficial for emigrants who want to keep ties with their native country, whose foreign language 
competence is very basic and who need instruction in the foreign language carried out in their native language. Furthermore, a virtual learning system offers opportunities for those emigrants who take their children with them, but want them to learn their native language or to maintain contact with their national and cultural identity.

Thus, the second part of the survey focused on an analysis of the participants' attitudes towards implementing ICT in the English language learning and teaching process. The data was obtained from the second part of the questionnaire, as well as the semi-structured interviews.

The study also aims to investigate the opportunities for the UK immigrants from Lithuania to improve their competence in English in their native country, and for their children who would like to study their parents' mother tongue, through the help of an online learning course presented by a prominent Lithuanian university. The data presented in Figure 6 reveal that more than half of the respondents (56 percent) would prefer blended language learning to other forms of learning. It is interesting to note that many of the students (31 percent) gave priority to distance learning, while only 13 percent of the respondents claimed that classroom learning would best suit their needs.

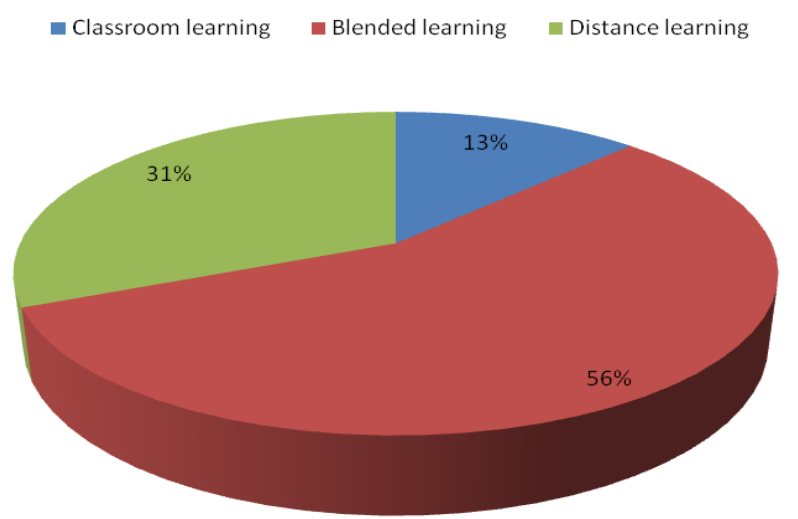

Fig. 6. Students' language learning preferences 
The study of the participants' attitudes showed that they generally found the integration of ICT in language learning to be effective, which suggests that ICT could become a cost-effective and time-saving solution that would enhance learning for English language learners both in the UK and in their native countries. The study also revealed that it is very difficult for some immigrants with different linguistic and cultural backgrounds to learn English, especially for people who work in isolated environments or communicate only with non-native English speakers. In this sense, native speakers' unwillingness to communicate with immigrants could be closely correlated to the learners' psychological barriers to speak English, which may result in low self-esteem and failure to make progress in English. Therefore, these obstacles to learning English (especially if it is delivered in a distant or blended way) should be considered (see Fig. 7):
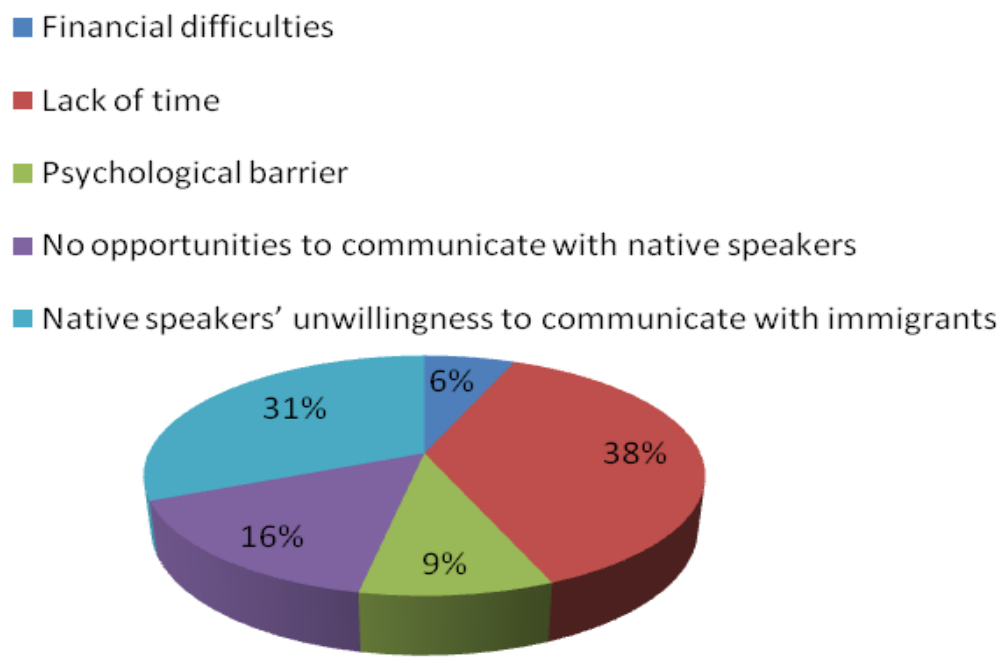

Fig. 7. Major obstacles to raising students' competence in English

Attention should be paid to the fact that for most of the immigrant adult learners, it is very difficult to play the role of a learner, because they have other 200 
important roles to play: often their primary responsibility is to their families, to creating a safe environment for their children, and to coping with family members' emotional stress and culture shock in a foreign country. As major obstacles to learning English, the respondents mentioned financial difficulties; lack of time; psychological barriers to learning a new language; being too old to learn languages effectively; the absence of opportunities to communicate with native speakers; and the unwillingness of native speakers to communicate with immigrants. Having these factors in mind, it is important to meet the educational and psychological needs of virtual learners with different life stories, learning styles and conditions for learning.

\section{Conclusions, recommendations and a perspective on further research}

The data presented in this study is primarily limited by the small sample size. In order to achieve more generalizable results with respect to the needs, experiences and attitudes of immigrant adult language learners, the sample size could be expanded by including more language learners of different nationalities and cultural backgrounds. Furthermore, the number of participants could be more evenly distributed across gender, education level, emigration time, and other variables. Including multiple ESOL course groups could diversify the ethnicities, ages, social and cultural backgrounds represented, as well. Therefore, the current study may be considered mainly in terms of its insights for developing further empirical studies.

However, based on the results of the present case, it can be concluded that the most important factors influencing the improvement of the participants' competence in English are their psychological well-being and their belief in the progress of their English studies. Exposure to real-life communicative situations; teaching innovative language learning strategies; addressing individual learning styles; and helping learners to develop social, inter-cultural, cognitive, problemsolving and time management skills could strongly influence their successful 
social, linguistic and cultural integration into a new country. Keeping in mind that the majority of the respondents mentioned their low self-esteem in a new country and an unusual/uncomfortable role of a learner at an older age, particular attention should be paid to helping such students improve their selfconfidence and creating flexible learning conditions.

As a means to address these unique needs, the researchers propose the following opportunity for Lithuanian emigrants and/or their children to improve their competence of English or Lithuanian with the help of online learning.

With the rapid popularity of distance teaching/learning in Lithuania, its universities are now offering a number of possibilities to study online. The quality of distance teaching/learning has extensively been researched by Lithuanian scholars (e.g., Lauzackas, 2001; Targamadz \& Cibulskis, 2006; Volungeviciene \& Tereseviciene, 2008; Zuzeviciute, \& Butrime, 2010). The application of ICT to English language teaching has also been investigated by the scholars of the Institute of Foreign Languages at a major Lithuanian university (e.g., Macianskiene \& Dauksiene, 2008; Pundziuvienè, 2012; Pundziuvienè, Bijeikienè, \& Linkevičiūtè, 2009; Pundziuvienè, Bijeikienè, \& Zutkiene, 2012). This institution provides learning opportunities for more than 30 modern and classical languages for its students, as well as other university and nonuniversity students, members of the wider university community and the general public. The increasing integration of distance education into language learning/teaching has influenced the emergence of a blended mode of teaching languages that has helped to ensure more flexible organization of language teaching and learning activities.

Such accessibility for learning languages provides conditions for cooperation and communication with Lithuanian emigrants from all over the world. The authors of the present paper believe that future perspectives with a particular focus on the accessibility of language and culture courses for Lithuanian emigrants should be analyzed. With respect to the needs of the participants in the present study for a teacher who could instruct in the students' native language and understand the educational and cultural backgrounds of 
Lithuanian learners of English, distance learning may not only help such students to raise their English competence in a less stressful way, but may also help them to maintain a connection with their native country. Having in mind that immigrant children often risk losing their national identity very quickly as they are forced to assimilate into a new culture, Lithuanian language and culture courses could help Lithuanian emigrant children to connect with their national language, history, culture, folklore, cuisine and customs.

The researchers hope that the ideas presented in this article will encourage further scientific research which will result in subsequent cooperation with English language teaching institutions or Lithuanian language schools in the UK and Lithuania, as well as the creation of distant language and culture courses for Lithuanian emigrants and their children.

\section{References}

Ambrose, S. A., Bridges, M. W., DiPietro, M., \& Lovett, M. C. (2010). How learning works: Seven research-based principles for smart teaching. San Francisco, CA: Jossey Bass.

Appleyard, N., \& Appleyard, K. (2010). Communicating with learners in the lifelong learning sector (5th ed.). Exeter, UK: Learning Matters.

Biggs, J., \& Tang, C. (2011). Teaching for quality learning at university $\left(4^{\text {th }}\right.$ ed.) Berkshire, UK: Open University Press.

Bijeikienè, V., Pundziuvienè, D., \& L. Zutkienè. (2012). IKT panaudojimas integruojant kalbos ir dalyko mokyma. Darnioji daugiakalbysté. Kaunas: VDU.

Bijeikienè, V., Linkevičiūtè, E., \& Pundziuvienè, D. (2009). ICT in foreign language learning and teaching: attitudes and practices. In Language and culture: New challenges for the teachers of Europe = Kalba ir kultūra: nauji iššūkiai Europos mokytojui (pp. 252-262). Vilnius: Vilniaus universiteto leidykla. 
CHALLENGES AND OPPORTUNITIES FOR UK IMMIGRANTS. LEARNING ENGLISH: A CASE STUDY OF ESOL CLASSES

Blanche, P., \& Merino, B. J. (1989). Self-assessment of foreign-language skills: Implications for teachers and researchers. Language Learning, 39(3), 313338.

Gravells, A. (2012). Preparing to teach in the lifelong learning sector (5th ed.). London: Learning Matters.

Laurel, D. (2010, April 8). How to engage adult learners - Six steps to adult learning success. In Ezine Articles. Retrieved from http://ezinearticles.com/?How-to-Engage-Adult-Learners---Six-Steps-toAdult-Learning-Success\&id $=4133709$

Lauzackas, R. (2001). Designing teaching curriculum. Kaunas, Lithuania: Vytautas Magnus University Press.

Macianskiene, N., \& Dauksiene, E. (2008). Impact of the use of ICT upon university students' approach to learning a foreign language. In F. Malpica, A. Tremante, F. Welsh \& B. Tait (Eds.), Proceedings of the 2nd international multi-conference on society, cybernetics and informatics (Vol. 1) (pp. 144-149). Orlando, FL,

Peterson, J. M. (2002). Toward whole schools: Building a movement for creativity and collaborative learning in the 21st century. In J. S. Thousand (Ed.), Creativity and collaborative learning: The practical guide to empowering students, teachers, and families. Baltimore: Paul H. Brookes.

Prince, M. (2004). Does active learning work? A review of the research. Journal of Engineering Education, 93(3), 223-231.

Pundziuvienè, D., Bijeikienè, V., \& Linkevičiūtè, E. (2009). ICT in foreign language learning and teaching: attitudes and practices. In Language and Culture: New Challenges for the Teachers of Europe, 18, 122-127.

Pundziuviene, D. (2012). Mišrusis bendrosios anglu kalbos mokymas/is: studentu požiūrio analizè. In Santalka: Filologija, Edukologija, 20(1), 7584.

Targamadz A., \& Cibulskis G. (2006). Development of modern e-learning services for Lithuanian distance education network LieDM. Paper 
presented at Informatics Education - The Bridge between Using and Understanding Computers, Vilnius, Lithuania.

Tisdell, E. (1995). Creating inclusive adult learning environments: Insights from multicultural education and feminist pedagogy. Information Series No. 361. Columbus: ERIC Clearinghouse on Adult, Career, and Vocational Education, Center on Education and Training for Employment, The Ohio State University.

Volungeviciene, A., \& Tereseviciene, M. (2008). Quality assessment dimensions of distance teaching/learning curriculum designing. The Quality of Higher Education, 5, 32-53.

Youngs, G., Ohsako, T., \& Medel-Añonuevo, C. (Eds.). (2001). Creative and inclusive strategies for lifelong learning. Hamburg: UNESCO Institute for Education.

Zuzeviciute, V., Butrime, E. (2010). E-learning as a socio-cultural System. In B. Ertl (Ed.), Technologies and practices for constructing knowledge in online environments: Advancements in learning. Hershey, PA: IGI Global.

\section{Jūratè Matulionienè}

Bostono lietuviu mokykla Rūta, Jungtinè Karalystè; ukjuma@yahoo.com Daiva Pundziuvienè Vytauto Didžiojo universitetas, Lietuva; d.pundziuviene@uki.vdu.It

\section{DIDŽIOSIOS BRITANIJOS IMIGRANTY ANGLY KALBOS MOKYMOSI IŠŠǓKIAI IR GALIMYBĖS: ESOL KURSU ATVEJO STUDIJA}

Santrauka. Anglu kalbos mokymosi poreikis tarp Didžiosios Britanijos imigrantu akivaizdus ir gausus besimokančiuju ivairove: kalbos mokymai reikalingi ne tik atvykusiems i šia šali ir patiriantiems kultūrini šoka, bet ir tiems, kurie jau ilga laika gyvena Didžiojoje Britanijoje, bet vis dar negeba kalbèti angliškai, nors ši kalba jiems būtina darbe. Tokie besimokantieji dažnai turi menką savivertę ir kitu psichologiniu problemu, kliudančiu išmokti užsienio kalbos. Nors didžioji dauguma anglu kalbos mokymosi proceso vyksta neformalioje aplinkoje, formalaus mokymo institucijos Didžiojoje Britanijoje arba imigrantu gimtosiose šalyse taip pat gali prisideti besimokant kalbos. Siekiant išanalizuoti suaugusiu besimokančiuju asmenu anglu kalbos mokymosi poreikius, buvo atliktas tyrimas, kurio pagrindinis tikslas - ištirti ESOL kursu dalyviu anglu kalbos mokymosi patirti ESOL kursuose. Taikant pusiau struktūruoto interviu metoda, buvo siekiama išsiaiškinti pagrindines kliūtis, trukdančias besimokantiesiems tobulinti anglu 
kalbos kalbinę kompetencija. Be to, tyrimu siekta atlikti anglu kalbos mokymo(si) galimybiu nuotoliniu būdu Lietuvos universitete analizę. Straipsnyje taip pat aptariamos galimybės organizuoti gimtosios kalbos mokymus lietuviu išeiviu vaikams, taikant nuotolinio mokymo formą. Tyrimas atskleide, kad esminiai faktoriai, salygojantys anglu kalbos kalbinès kompetencijos tobulinimo sékmę, yra pozityvi besimokančiuju savijauta mokymo(si) proceso metu ir tikèjimas būsima mokymosi pažanga. Atliktas tyrimas taip pat parodè, kad tokiu socialiai jautriu besimokančiu kalbos asmenu dèstytojams derètu taikyti inovatyvias kalbos mokymo strategijas, atsižvelgti $i$ individualius mokymosi stilius ir stengtis tobulinti ne tik kalbinius, bet ir socialinius, tarpkultūrinius, kognityvinius, problemu sprendimo ir laiko organizavimo igūdžius. Mišrus anglu kalbos mokymas(is) galètu padèti mokymo(si) procesa pritaikyti prie besimokančiuju edukacinès, lingvistinès ir kultūrinès patirties.

Pagrindinès sąvokos: anglu kalba kitakalbiams (ESOL), Didžiosios Britanijos imigrantu anglu kalbos mokymasis, savivertè ir anglu kalbos mokymasis, akultūracija, ESOL Didžiojoje Britanijoje, inkliuzinio mokymo strategijos, nuotolinis mokymasis. 